\title{
Mechanistic insights into xanthine oxidoreductase from development studies of candidate drugs to treat hyperuricemia and gout
}

\author{
Takeshi Nishino $\cdot$ Ken Okamoto
}

Received: 3 September 2014 / Accepted: 21 October 2014 / Published online: 12 December 2014

(C) The Author(s) 2014. This article is published with open access at Springerlink.com

\begin{abstract}
Xanthine oxidoreductase (XOR), which is widely distributed from humans to bacteria, has a key role in purine catabolism, catalyzing two steps of sequential hydroxylation from hypoxanthine to xanthine and from xanthine to urate at its molybdenum cofactor (Moco). Human XOR is considered to be a target of drugs not only for therapy of hyperuricemia and gout, but also potentially for a wide variety of other diseases. In this review, we focus on studies of XOR inhibitors and their implications for understanding the chemical nature and reaction mechanism of the Moco active site of XOR. We also discuss further experimental or clinical studies that would be helpful to clarify remaining issues.
\end{abstract}

Keywords Xanthine oxidase - Uric acid - Allopurinol · Febuxostat · Gout

\section{Introduction}

Xanthine oxidoreductase (XOR), which can act as a xanthine oxidase or xanthine dehydrogenase, exists in a wide

Responsible Editors: José Moura and Paul Bernhardt.

T. Nishino $(\bowtie) \cdot$ K. Okamoto

Department of Biochemistry and Molecular Biology, Nippon

Medical School, 1-1-5 Sendagi, Bunkyou-ku, Tokyo 113-8602,

Japan

e-mail: nishino@nms.ac.jp

T. Nishino

Department of Applied Biological Chemistry, Graduate School of Agricultural and Life Sciences, University of Tokyo,

1-1-1 Yayoi, Bunkyo-Ku, Tokyo 113-8657, Japan variety of organisms from bacteria to plants to humans [1, 2]. It catalyzes the reaction steps from hypoxanthine to xanthine and from xanthine to uric acid in the pathway of purine metabolism (Fig. 1); some aldehydes are also good substrates. The enzyme was first isolated from cow's milk as aldehyde oxidase in 1902 [3], and was subsequently shown [4] to be the same as the enzyme previously identified as xanthine oxidase in milk [5]. XOR contains a molybdenum cofactor (Moco; molybdopterin), two nonidentical $[2 \mathrm{Fe}-2 \mathrm{~S}]$ clusters, and one FAD per subunit of the dimeric protein, which has a total molecular weight (MW) of about $300 \mathrm{kDa}$. This enzyme is the best-studied complex flavoprotein, and several reviews are available [1, 2, 6-15].

In primates or uricoteric animals, uric acid is the end product of purine catabolism and is formed in cytosol [16]. However, in other organisms, e.g., in mammalians other than primates, uric acid is further oxidized to allantoin by uricase in peroxisomes [17-19]. Humans have lost uricase during evolution [20], and secrete uric acid mainly via kidney and partially via intestine. In kidney, uric acid is recovered via nephron transporter URAT1 [21] and also via ABCG2 transporter [22-24]. ABCG2 also mediates uric acid secretion from intestine, and a defect of this activity is one of the reasons for hyperuricemia [25]. A blood uric acid concentration higher than $7 \mathrm{mg} / \mathrm{dL}$ is a risk factor for gout [26] and is also proposed to be an independent risk factor for various diseases related to so-called metabolic syndrome [27], as well as kidney diseases [28] and endothelial dysfunction [29-32]. In order to decrease the concentration of uric acid in blood, drugs that inhibit biosynthesis or increase secretion of uric acid have been used clinically [33]. The XOR inhibitor allopurinol, an isomer of hypoxanthine, has been used to treat gout for more than 40 years, and the efficacy of XOR inhibition as a strategy for prevention of gout attack is well established. However, 
Fig. 1 Schematic illustration of purine metabolism in primates. Hypoxanthine formed from inosine is hydroxylated to afford xanthine. Xanthine is also formed from guanine by deamination. Xanthine is further hydroxylated to uric acid (the final product in primates) in cytosol. Uric acid is converted to allantoin in peroxisomes of other mammalian species

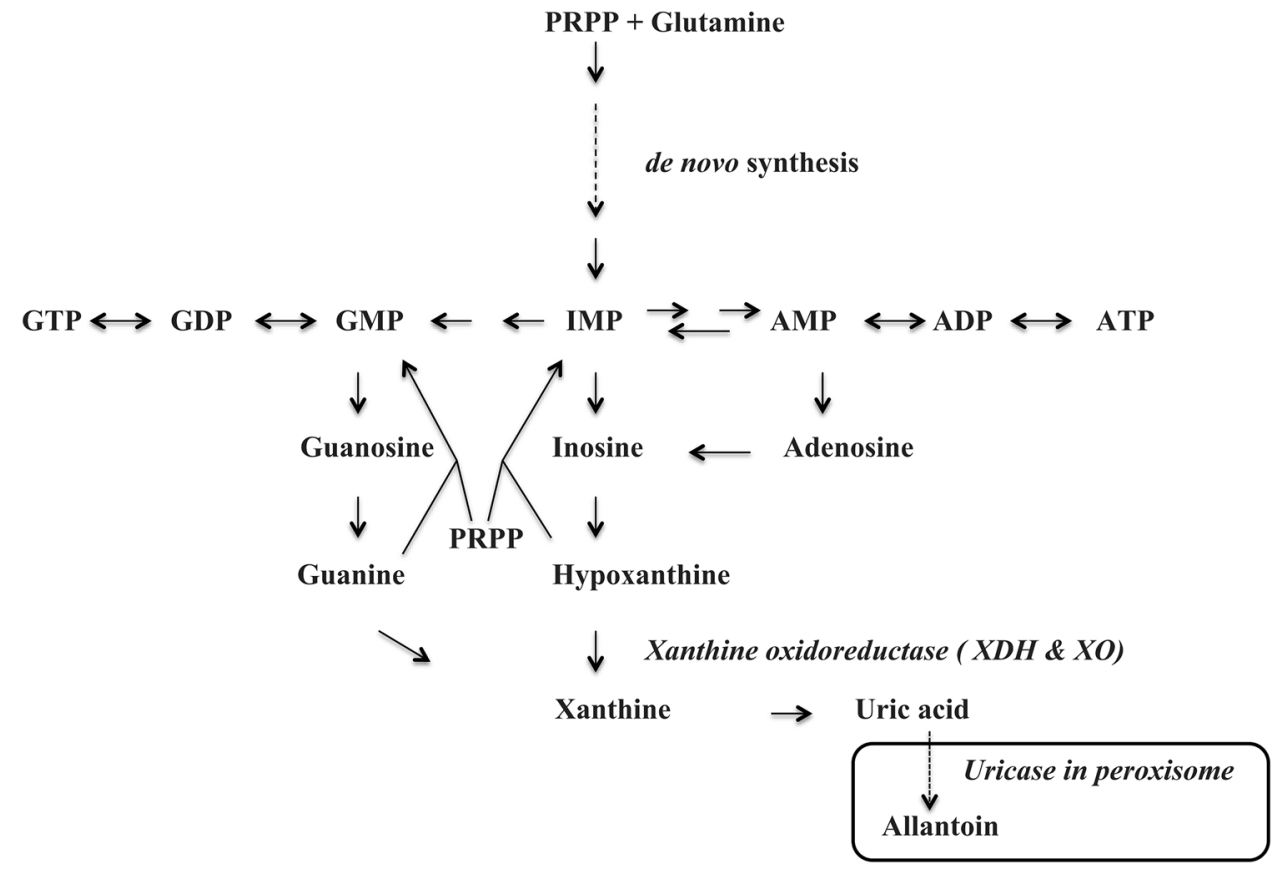

in some cases allopurinol causes serious adverse effects $[34,35]$, and so new inhibitors of uric acid formation have been sought to replace it in such cases. Indeed, a patent survey indicated that more than 250 XOR inhibitors have been investigated as candidate drugs [36]. However, none of them, other than allopurinol, has been approved until quite recently: febuxostat was approved in EU countries in 2008, in the USA in 2009, and subsequently in various other countries including Japan (2011). Another inhibitor, topiroxostat, has also been approved recently in Japan (2013). In this paper, we review the implications of enzymological and developmental studies of XOR inhibitors for understanding the chemical nature and reaction mechanism of the Moco active site of XOR.

\section{Brief overview of XOR}

Mammalian XOR exists as a homodimer of $150 \mathrm{kDa}$ subunits; its three-dimensional and primary structures are illustrated in Fig. 2. Each of the subunits is composed of three domains. The largest, C-terminal domain contains the molybdenum cofactor (Moco), the intermediate domain contains flavin adenine dinucleotide (FAD) cofactor and the smallest, N-terminal domain contains the two iron sulfur clusters ([2Fe-2S] type). The redox reaction centers are positioned in the order of Moco, the two iron clusters and FAD with an overall separation of less than $14 \AA$, as is usually the case for electron transfer components [37-41]. The iron sulfur clusters are designated Fe/S I and Fe/S II [42-45]; Fe/S II has the higher redox potential, and shows unusually broad EPR signals at temperatures below $22 \mathrm{~K}$, whereas Fe/S I is typical plant ferredoxin-type center [44]. Assignment of these clusters in the primary structure was performed by means of site-directed mutagenesis studies [43]. The hydroxylation reaction of purine takes place at Moco; firstly, two electrons are transferred from the substrate to Mo of Moco, reducing Mo(VI) to Mo(IV); Mo(V) is observed only transiently. It is considered that $\mathrm{H}^{+}+2 \mathrm{e}^{-}$ derived from the substrate, in the form of hydride $\left(\mathrm{H}^{-}\right.$, i.e., a hydrogen atom with two electrons) is transferred to a sulfur ligand of Moco $(\mathrm{Mo}(\mathrm{VI})=\mathrm{S} \rightarrow \mathrm{Mo}(\mathrm{IV})-\mathrm{SH})[1$, 46, 47]. The $\mathrm{Mo}(\mathrm{V})$ species is not formed by one-electron transfer from the substrate, but rather is formed during the process of electron transfer from Mo to the iron sulfur center. Electrons are transferred to FAD via the iron sulfur centers in the order illustrated in Fig. 2. Finally, $\mathrm{NAD}^{+}$or oxygen molecule receives an electron from FAD to afford $\mathrm{NADH}$ or $\mathrm{H}_{2} \mathrm{O}_{2}$ and $\mathrm{O}_{2}{ }^{-}$, respectively. XOR from most organisms uses $\mathrm{NAD}^{+}$as an electron acceptor and is called xanthine dehydrogenase $(\mathrm{XDH})$, while XOR proteins from mammals can be converted to the oxidase form (XO), which uses exclusively the oxygen molecule as an electron acceptor [48-52]. The conversion involves posttranslational modification such as disulfide formation or proteolytic nicking of the same XOR gene product [2, 53-55]. Historically, XOR was isolated from cow's milk after irreversible conversion to $\mathrm{XO}$ by nicking the enzyme with pancreatin to isolate it from milk fat globule membrane [56], so the enzyme has been called 'xanthine oxidase', but it is considered that the enzyme actually exists in xanthine dehydrogenase form [48, 57]. The physiological and pathological 
Fig. 2 Structure of bovine XOR. Top Primary structure of bovine XOR subunit illustrated as three domains connected with two linker peptides. The $\mathrm{N}$-terminal (red), the C-terminal (blue) and the intermediate (yellow) domains contain the iron-sulfur centers, the Moco center and the FAD center, respectively. Middle left Homodimer structure of bovine XOR illustrated with one subunit as a ribbon model and the other as a space-filling model. Right Cofactor arrangement. Figures were generated from PDB ID 1F4Q. Bottom Hydroxylation reactions of hypoxanthine to xanthine and xanthine to uric acid.

Two electrons are transferred to the Mo atom of Moco
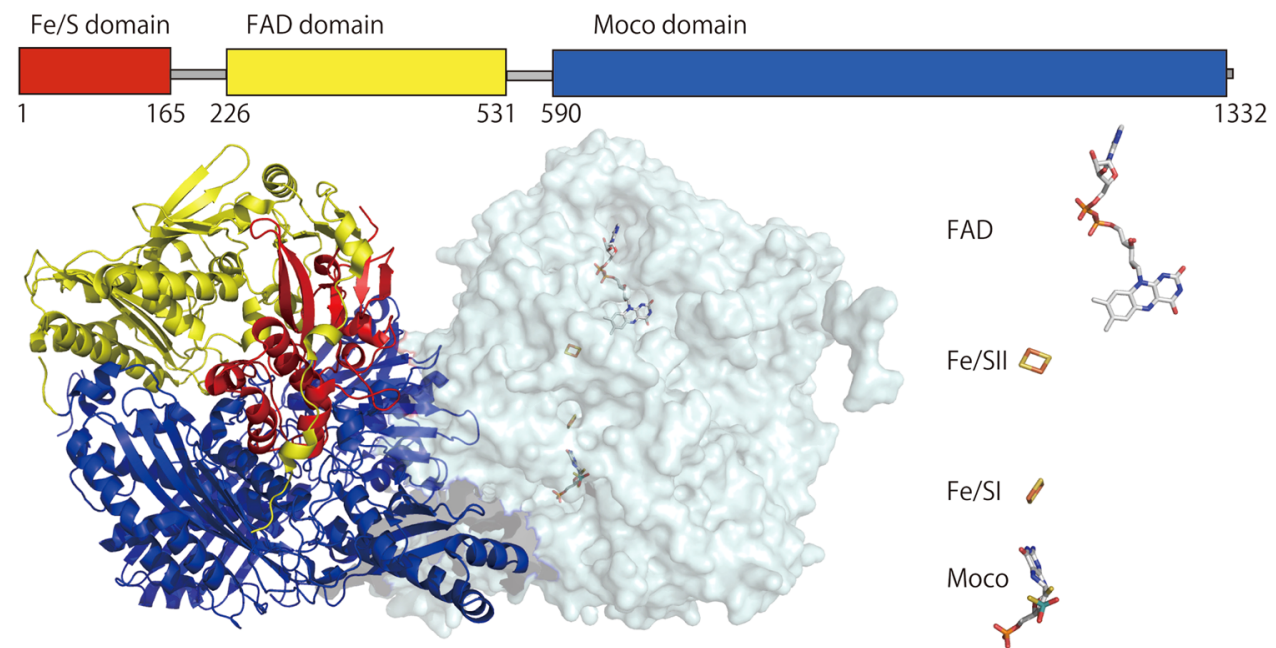

$\mathrm{Fe} / \mathrm{SII} \otimes$

Moco<smiles>[Y][C@H](C)[C@H](C)[C@@H](C)O</smiles><smiles>C[14CH2][14C@H](C)[14CH2]O</smiles>

uric acid roles of the conversion have long attracted attention, particularly from researchers in the medical field, but remain controversial $[6,12,14,58]$, although the mechanism of the conversion is well understood and has been reviewed in detail [10].

\section{Inhibitor characteristics and inhibitory mechanism}

\section{Allopurinol}

Allopurinol (4-OH-pyrazolo-pyrimidine) has been used as an anti-gout drug for over 40 years. It was synthesized by Robins [59] and introduced into clinical use by Elion et al. [60]. It is an isomer of hypoxanthine, and was initially reported to be a simple competitive inhibitor that binds to the molybdenum center competitively with respect to xanthine, with the $K_{i}$ value of $7 \times 10^{-7} \mathrm{M}$ for the rat enzyme and $1.9 \times 10^{-7} \mathrm{M}$ for the human enzyme [61]. The $\mathrm{IC}_{50}$ value was reported as $1,700 \mathrm{nM}$ [36]. However, it subsequently became clear that the inhibitory mechanism of allopurinol is more complicated and potent than initially envisaged [62, 63]. Massey et al. [63] showed that the inhibition progresses in a time-dependent manner, with eventual formation of a tightly bound complex of the reduced enzyme (MoIV) with oxipurinol (often called alloxanthine) generated by hydroxylation of allopurinol, as illustrated in Fig. 3A. The reason for the time dependence of the inhibition is the time taken to convert allopurinol to oxipurinol and to trap reduced MoIV that is transiently formed during enzymatic turnover.
The oxipurinol-molybdenum complex dissociates upon reoxidation of $\mathrm{Mo}(\mathrm{IV})$ in air $\left(t_{1 / 2}=300 \mathrm{~min}\right.$ at $\left.25^{\circ} \mathrm{C}\right)$ due to electron transfer to oxidized cofactors [63, 64]. Massey et al. [63] also concluded that the naturally isolated enzyme contained a significant amount of inactive form that could not bind oxipurinol, since the molar ratio of oxipurinol per enzyme FAD was less than one, and was correlated linearly to the specific activity of various enzyme samples. They found subsequently that the inactive form is identical to the inactive enzyme generated by treatment with $\mathrm{KCN}$, which releases a sulfur atom at the active site that is essential for catalytic activity. They also found that the inactive enzyme could be reactivated to the active sulfo form by $\mathrm{Na}_{2}^{35} \mathrm{~S}$ treatment, with incorporation of a stoichiometric amount of ${ }^{35} \mathrm{~S}$ into the enzyme $[65,66]$. Thus, studies on the XOR inhibitor allopurinol yielded the important finding that the sulfide ligand is essential for enzymatic activity. It was subsequently shown that sulfide is one of the coordinating ligands of the Mo atom [67]. Separation of the active and inactive forms of the enzyme was attempted by Edmondson et al. [68] using an affinity-gel-linked allopurinol analog with a long-chain ligand at the 5-position. On the other hand, Nishino et al. [69, 70] used allopurinol in a rather different way: they applied the Mo(IV)-oxipurinol enzyme complex to folate affinity gel, which binds the free active site of any enzyme species, including the inactive desulfo form, and then they reactivated the passed-through fraction of Mo(IV)-oxipurinol complex by oxidation with ferricyanide. Thus, studies using allopurinol provided important information about the presence of the inactive desulfo form in the naturally isolated enzyme 
A

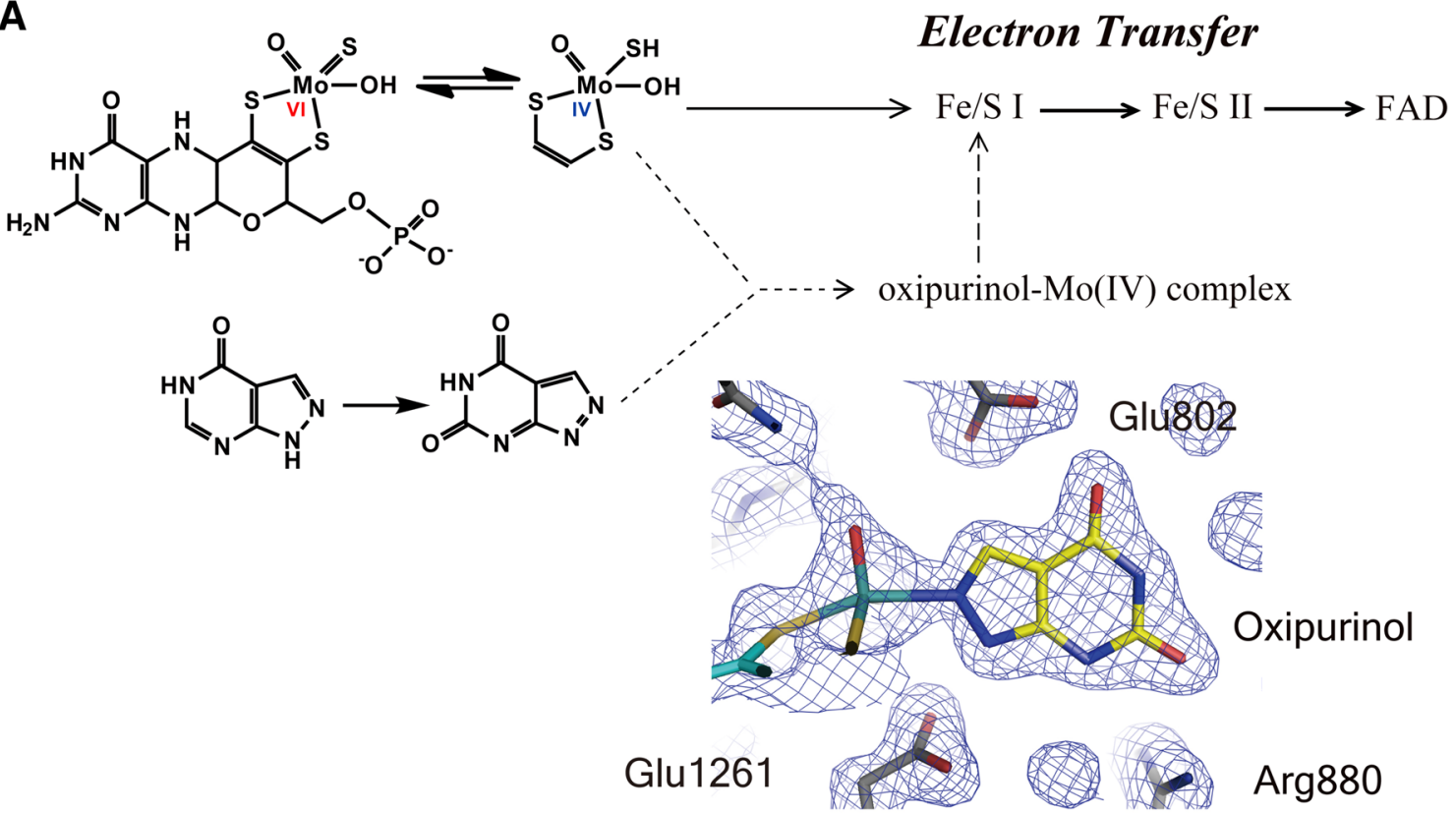<smiles>Cc1cccc(C2C=NN3C2=NC(O)=NC3O)c1</smiles><smiles>CC(=O)Nc1cccc(N2C=NC3C2=NC(N)=NC3O)c1</smiles><smiles>c1cc(-c2nc(-c3ccncn3)n[nH]2)ccn1</smiles><smiles>Nc1c(-c2cccc(C(F)(F)F)c2)nsc1C(=O)O</smiles><smiles>CCC(=O)c1sc(-c2ccc(OCC(C)C)c(C#N)c2)nc1C(=O)O</smiles>

Fig. 3 Inhibitors of XOR. A Mechanism of inhibition of XOR by allopurinol. Allopurinol is a good substrate of XOR and is converted to oxipurinol with concomitant reduction of Mo (VI) to Mo(IV). Mo(IV) is mainly re-oxidized via electron transfer to the other cofactors in XOR. During turnover, Mo(IV) reacts with oxipurinol to form a tightly bound complex; its crystal structure is shown as an electrondensity map. B Representative potent inhibitors reported after the clinical application of allopurinol. (a) from ICN Pharma: $\mathrm{IC}_{50}, 25$ $\mathrm{nM}$; $(b)$ from C. Silipo: $\mathrm{IC}_{50}, 10 \mathrm{nM}$; (c) from E. Merck: $\mathrm{IC}_{50}, 40$ $\mathrm{nM}$; d ) from Eli Lilly: $\mathrm{IC}_{50}, 13 \mathrm{nM}$. In box inhibitors that have been examined in detail, including crystal structure of the XOR-bound form. (e) BOF-4272; $(f)$ febuxostat, TEI-6720; $(g)$ pyranoxostat, Y-700; $(h)$ topiroxostat, FYX-051 
and the action mechanism of allopurinol as a suicide inhibitor, as well as providing a basis for separation of inactive enzyme. Before discovery of the desulfo form, Bray et al. had reported that XO isolated from bovine milk contains an inactive demolybdo form in a small amount that depended on the season and the location where the cows had grazed. These results suggested that the content of demolybdo form depends on the nutritional status of cows [71]. Nishino et al. [69] also noted that XOR isolated from Japanese cows' milk contains a very small amount of inactive demolybdo form that can be isolated by first folate affinity column chromatography (passed-through fractions), as shown previously. Similar results were observed for American cows' milk (unpublished observations). On the other hand, Harrison et al. [72, 73] reported that XOR isolated from human milk was mostly in demolybdo form. In contrast, however, Moriwaki et al. [74] or Krenitsky et al. [75] reported purification and characterization of human liver enzyme and showed that its activity is not greatly different from that of normal bovine milk XOR. The content of inactive enzyme is an important issue in evaluating the effects of XOR inhibitors in vivo, since structure-based inhibitors can bind to inactive enzyme species, as described later, and this would decrease the efficacy of drugs by lowering the free inhibitor concentration in blood.

\section{Inhibitors other than allopurinol}

Various inhibitors were reported after the introduction of allopurinol, but most of them have not been approved for clinical use. Potent inhibitors identified from a patent survey or reported in the literature [76-79] are shown in Fig. 3B, together with their $\mathrm{IC}_{50}$ values (inhibitor concentration required to inhibit the enzyme activity by $50 \%$ ). Other new XOR inhibitors have also been reported in the last few years (structures not shown here) [80-92]. However, it should be pointed out that the $\mathrm{IC}_{50}$ values are not necessarily reliable. For example, as described in the previous section, allopurinol is a potent suicide inhibitor, so its potency cannot be shown in terms of $\mathrm{IC}_{50}$, i.e., inhibition is dependent upon incubation time, enzyme concentration and percent of active form of the enzyme. In most cases, detailed enzymological or pharmacological data for the inhibitors were not reported, except in the case of 2-phenyl-4-methyl-1,3-selenazole-5-carboxylic acid (PMSC), for which $K_{i}$ and $K_{i}^{\prime}$ values were given, in addition to a docking study [89]. Here, in order to illustrate the utility of XOR inhibitor studies for understanding the chemical nature and reaction mechanism of the enzyme, we will focus on the inhibitors BOF-4272, TEI-6720, Y-700 and FYX-051, which were characterized in detail using fully active bovine XO after the mid-1980s (Fig. 3B in box). The last compound will be described in the next section.
BOF-4272

Sodium-8-(3-methoxy-4-phenylsulfinylphenyl)pyraz olo[1,5-a]-1,3,5-triazine-4-olate monohydrate (BOF-4272) is separable into the $(-)$-isomer and $(+)$ isomer by HPLC using a Chiralcel OD column. The (-)-isomer showed much higher affinity for the enzyme, and steady-state kinetics showed mixed-type inhibition with $K_{i}=1.2 \times 10^{-9} \mathrm{M}$ and $K_{i}^{\prime}=9 \times 10^{-9} \mathrm{M}$ for xanthine and oxygen as substrates, whereas the (+)-isomer showed $K_{i}=3 \times 10^{-7} \mathrm{M}$ and $K_{i}^{\prime}=9 \times 10^{-6} \mathrm{M}$ [93]. A plausible explanation for the mixed-type inhibition is the difference of $K_{i}$ for oxidized and $K_{i}^{\prime}$ for reduced enzyme [93], and this may also be the case for other inhibitors (Fig. 3B in box). Although BOF-4272 was a potent inhibitor in animal experiments [94], clinical studies indicated that its efficacy varies from individual to individual; in some cases it was as effective as allopurinol on a weight basis, but in others it was less effective. It was concluded that the drug concentration in blood was insufficient, probably due to hepatic metabolism, as well as poor absorption of the drug from the intestine. Overall, this work indicated that uric acid production in humans occurs not only in liver, but also to a significant extent in other organs, whereas other animals produce uric acid predominantly in liver. Thus, it may be necessary to use a more potent inhibitor $\left(K_{i}\right.$ value less than $\left.10^{-9}\right)$ and to achieve a higher concentration of inhibitor in blood to obtain clinical efficacy. The lessons learned during the work on BOF-4272 contributed greatly to the development of the following inhibitors as clinically useful drugs.

\section{Febuxostat (TEI-6720; (2-[3-cyano-4-isobutoxyphenyl]- 4-methyl-5-thiazolecarboxylic acid) [105] and pyranostat (Y-700; 1-[3-cyano-4-(2,2-dimethylpropoxy)phenyl]- 1H-pyrazole-4-carboxylic acid)}

These compounds were synthesized and selected by Kondo et al. [95] and Fukunari et al. [96] at Teijin Co. and Mitsubishi Pharma Co., respectively, from among various synthesized compounds based on the criteria of $K_{i}$ value less than $10^{-9} \mathrm{M}$ using fully active enzyme and good solubility. Both of them showed mixed-type inhibition in steady-state kinetic studies using fully active enzyme, like BOF-4272. It should be noted that inhibition of XOR by febuxostat is not linear with time [95], so steady-state analysis based on initial velocity was employed. The $K_{\mathrm{d}}$ value of XOR-febuxostat was too low to measure, even with a sensitive florescence detection method. Based on the crystal structure and MD simulation, it was proposed that the protein structure around the Moco cavity has a dynamic open structure in solution, but adopts a more compact structure after binding of the inhibitor in the protein cavity [97]. This idea is consistent with the fact that we have succeeded in crystallizing 
many mammalian XOR proteins, including mutants, only in the presence of additional compounds such as inhibitors. XOR in which the Moco cavity is unoccupied has never been crystallized.

\section{Crystal structures of XOR bound with salicylate, oxipurinol, BOF-4272, febuxostat, and pyranostat}

\section{Salicylate}

The crystal structure of bovine XOR was first determined as the salicylate-bound form (Fig. 4A) [37]. Salicylate, a weak competitive inhibitor, is normally included during purification to prevent conversion of sulfo-XOR to inactive desulfo-XOR. In the XDH crystal structure, the salicylate molecule is bound $6.5 \AA$ from the Mo ion, in a position that would be overlapped by larger aromatic substrates (hypoxanthine or xanthine) present at the binding site. Thus, although salicylate itself does not bind to the Moco, it blocks the approach of substrates to the metal complex. Salicylate binding is mediated by several hydrogen bonds and electrostatic interactions. The inhibitor is aligned parallel to the phenyl ring of Phe 914, but the two aromatic rings only slightly overlap. At the same time, the phenyl ring of Phe 1009 interacts edge-on with the center of the salicylate ring. Both of the carboxylate atoms are close to the guanidinium group of Arg 880 and they also interact with the hydroxyl side chain of Thr 1010 and via a water molecule with the carboxylate of Glu 1261. The salicylate hydroxyl group forms hydrogen bonds to both the backbone amide and hydroxyl side chain of Thr 1010.

Oxipurinol (Allopurinol)

The crystal structure of the complex of pre-reduced fully active bovine XO with oxipurinol was determined at $2.0 \AA$ resolution [98]. Strong electron density connected oxipurinol and the Mo atom (Fig. 3A). The $\mathrm{N}_{2}$ nitrogen of oxipurinol replaces the equatorial hydroxyl ligand of the molybdenum atom, coordinating directly to the metal atom at a distance of $2.3 \AA$ with a $180^{\circ}$ angle between Mo-ion, $\mathrm{N}_{2}$-atom and the pyrazole ring (Figs. 3A, 4A). The other position is occupied by the $-\mathrm{SH}$ atom located at a distance of about $2.4 \AA$ from the central metal ion, in accordance with the previously described mechanism of inhibition by allopurinol. Oxipurinol forms hydrogen bonds with Glu802 via its 4-position $(=\mathrm{O}$; corresponding to the 6-position of xanthine), $\operatorname{Arg} 880$ via its 6-position ( $=\mathrm{O}$; corresponding to the 2-position of xanthine) and Glu1261 via N1. These interactions provide clues to the binding mode of substrate xanthine, an isomer of oxipurinol, as will be discussed below.

\section{BOF-4272, Febuxostat and pyranostat}

The crystal structures of the complexes of milk XOR with BOF-4272, febuxostat and pyranostat show features that account for the tight binding; these inhibitors fit well into the substrate-binding channel of XOR, and no
A

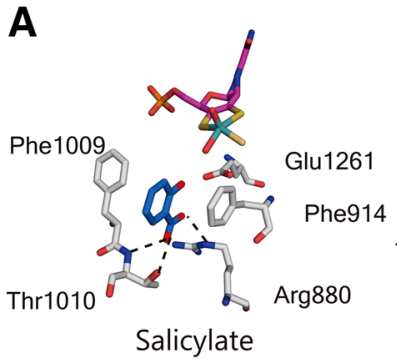

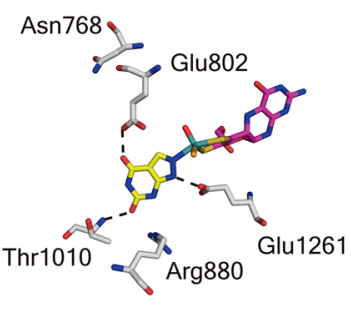

Oxipurinol

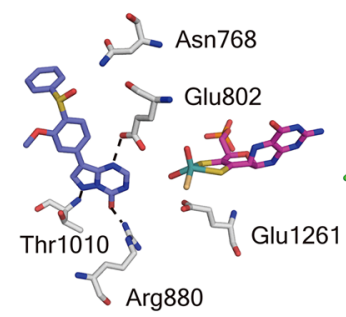

BOF-4272

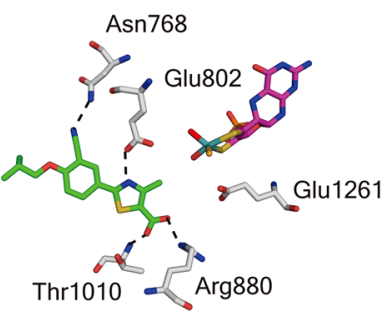

Febuxostat(TEI-6720)

B

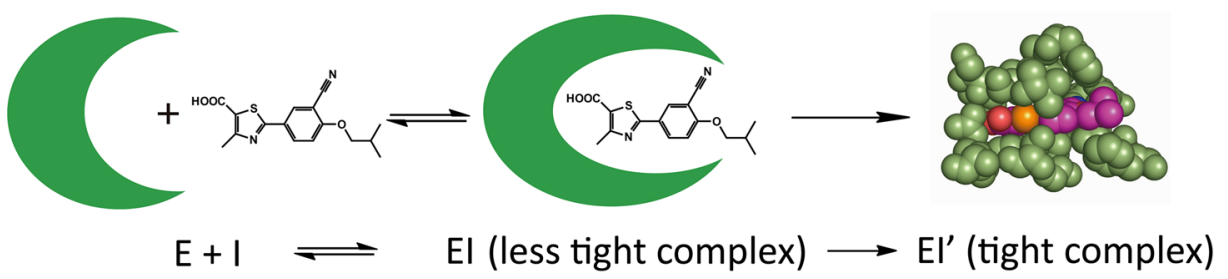

Fig. 4 Crystal structures of potent inhibitors bound to the XOR Moco center. A Inhibitors and amino acid residues are illustrated by stick models with atom colors reproduced from PDB. Salicylate, PDB:1FO4; oxipurinol, PDB:3BDJ; BOF-4272: data deposition in process; Febuxostat, PDB:1N5X. B Schematic model of interaction of febuxostat with the active site cavity. Interaction of febustostat with the open cavity affords a weakly bound complex with the $K_{i}$ values determined by steady-state kinetics using initial velocity, and this is subsequently converted to a tightly bound complex, of which the $K_{\mathrm{d}}$ value is too low to be determined accurately (see text) 
open space remains in the channel after binding of these compounds. Docking study of PMSC, which has higher potency than febuxostat, probably due to replacement of $S$ by $\mathrm{Se}$, suggested that PMSC may also fill the space in the same region, although the crystal structure was not available [80]. In contrast to oxipurinol, febuxostat and pyranostat do not form a covalent bond with molybdenum. However, multiple weak interactions, such as ionic and hydrogen bonds, $\pi-\pi$ interactions between the main fivemembered ring and nearby phenylalanine residues, van der Waals interactions, and hydrophobic interactions [95], result in tight binding; the dissociation constants are very low. Moreover, the fit of these compounds to the enzyme's active-site structure is enhanced by rotation of the region between the five-membered ring and the benzene ring. Thus, these inhibitors efficiently match the structure of the substrate-binding region of the enzyme. A hydrogen-bonding interaction of the $\mathrm{CN}$ group of the inhibitors with an asparagine residue of the enzyme should be noted. In the crystal structure, the side chain amide of Asn768 and the CN group at the 3-position are only $\sim 3 \AA$ apart $[94,96]$. Although this asparagine residue is located too far from the active center for direct involvement in purine substrate recognition or catalytic activity, the $\mathrm{CN}$ group of these inhibitors is necessary for potent enzyme inhibitory activity. A bulky hydrophobic moiety at the 4-position is also essential for tight binding. The 4-isobutoxy group is surrounded by hydrophobic amino acids at distances of around $4 \AA$ [96]. Interestingly, these crystallographically determined features of the inhibitor binding mode suggest that the fit of the inhibitors in the cavity is too tight to allow entry of the inhibitors into the cavity, as shown in Fig. 4B, suggesting that initially the inhibitors bind rather weakly to an open form of the dynamic protein structure. The $K_{i}$ and $K_{i}^{\prime}$ values determined by steady-state kinetics using initial rate would reflect this, while the $K_{\mathrm{d}}$ values for the subsequent tight interaction are too low to determine accurately. Interestingly, these structure-based inhibitors do not efficiently inhibit bacterial XOR, even though its crystal structure is very similar and important amino acid residues involved in catalysis are conserved. MD simulation study indicated that the mobility of the active-site cavity is altered due to replacement of amino acid residues not involved in catalysis, providing further evidence for the dynamic flexibility of Moco in the active site [97].

Topiroxostat: (FYX-051, 4-[5-Pyridin-4-yl-1H-[1, 2, 4] triazol-3-yl]pyridine-2-carbonitrile)

It is a potent inhibitor that serves as a suicide substrate of XOR [99, 100] and also has similar features to structure-based inhibitors such as febuxostat and pyranostat. Topiroxostat transfers two electrons to the enzyme, forming a stable complex with Mo(IV) within a short time [98]. In the crystal structure of the complex of fully active $\mathrm{XDH}$ and topiroxostat at $1.9 \AA$ resolution (Fig. 5A, B), it was seen that one of the $\mathrm{C}$ atoms of topiroxostat, next to the $\mathrm{N}$ atom, forms a covalent bond with molybdenum through oxygen. The bridging electron density between the Mo and $\mathrm{C}$ atoms is bent at an angle of $152^{\circ}$, and spans $3.3 \AA$ in total (Mo-O, $2.0 \AA$ and $\mathrm{O}-\mathrm{C}, 1.3 \AA$ ), indicating Mo-O-C bond formation. It had not been possible to identify definitively the chemical nature of atoms bound to the Mo atom based on electron density alone in the previous lower-resolution crystal structure with $\mathrm{XDH}$ that was not fully active [37], but three ligands of the Mo atom were tentatively assigned as $=\mathrm{S},=\mathrm{O}$, and $-\mathrm{OH}$ according to the previously proposed geometry [101]. However, at higher resolution, with fully active $\mathrm{XDH}$, the topiroxostat-inhibited $\mathrm{XDH}$ structure provided an updated geometry of the Mo ligands and the ligands were definitely assigned as $=\mathrm{S}(-\mathrm{SH}$ in reduced Mo) and $-\mathrm{O}-\mathrm{C}-$ at the equatorial position, and $=\mathrm{O}$ at the apical position from reduced Mo (IV), as shown in Fig. 5, by comparison with the structure of desulfo-XO bound with the same inhibitor (Fig. 5C, D). This updated geometry is consistent with magnetic circular dichroism findings [102], X-ray absorption spectroscopy [103] and analysis of model compounds. Various interactions, including hydrogen bonding with surrounding amino acids, hydrophobic interaction and $\pi-\pi$ stacking interaction with two phenylalanines, were observed, similarly to the cases of febuxostat and pyranostat. Mo(IV)-O-C- of the initially formed complex of $\mathrm{Mo}(\mathrm{IV})$-topiroxostat decomposed with a half-life of approximately $20 \mathrm{~h}$ at $25^{\circ} \mathrm{C}$ and formed another complex interacting in different manner [100]. The structure of this complex provided important insight into the hydroxylation mechanism. An identical structure was formed when dithionite-reduced Mo(IV) was mixed with hydroxy topiroxostat. It was shown that protonated Glu1261 forms a hydrogen bond with substrate nitrogen next to the carbon atom to be hydroxylated, suggesting an important role of protonated Glu1261, i.e., hydrogen bonding to the nitrogen atom facilitates nucleophilic attack on adjacent carbon by the basic oxygen atom (Mo-O-) [99]. This concept is consistent with the role of the side chain of a glutamic acid residue near the Mo-OH group in the reaction of aldehyde oxidoreductase (ALO) from the sulfate-reducing anaerobic bacterium Desulfovibrio gigas [101]. Thus, it can be expected that a $\mathrm{C}$ atom of various $N$-heterocyclic compounds can be hydroxylated, if the compounds have affinity for the active-site cavity. We believe that physiological substrates are also activated in essentially the same manner. When this glutamic acid residue was altered by mutagenesis to alanine, the activity was completely lost [104]. The rate-limiting step is cleavage of the Mo-O-C bond by a water molecule to give $\mathrm{Mo}-\mathrm{OH}$ plus $\mathrm{C}-\mathrm{OH}$, but no such 

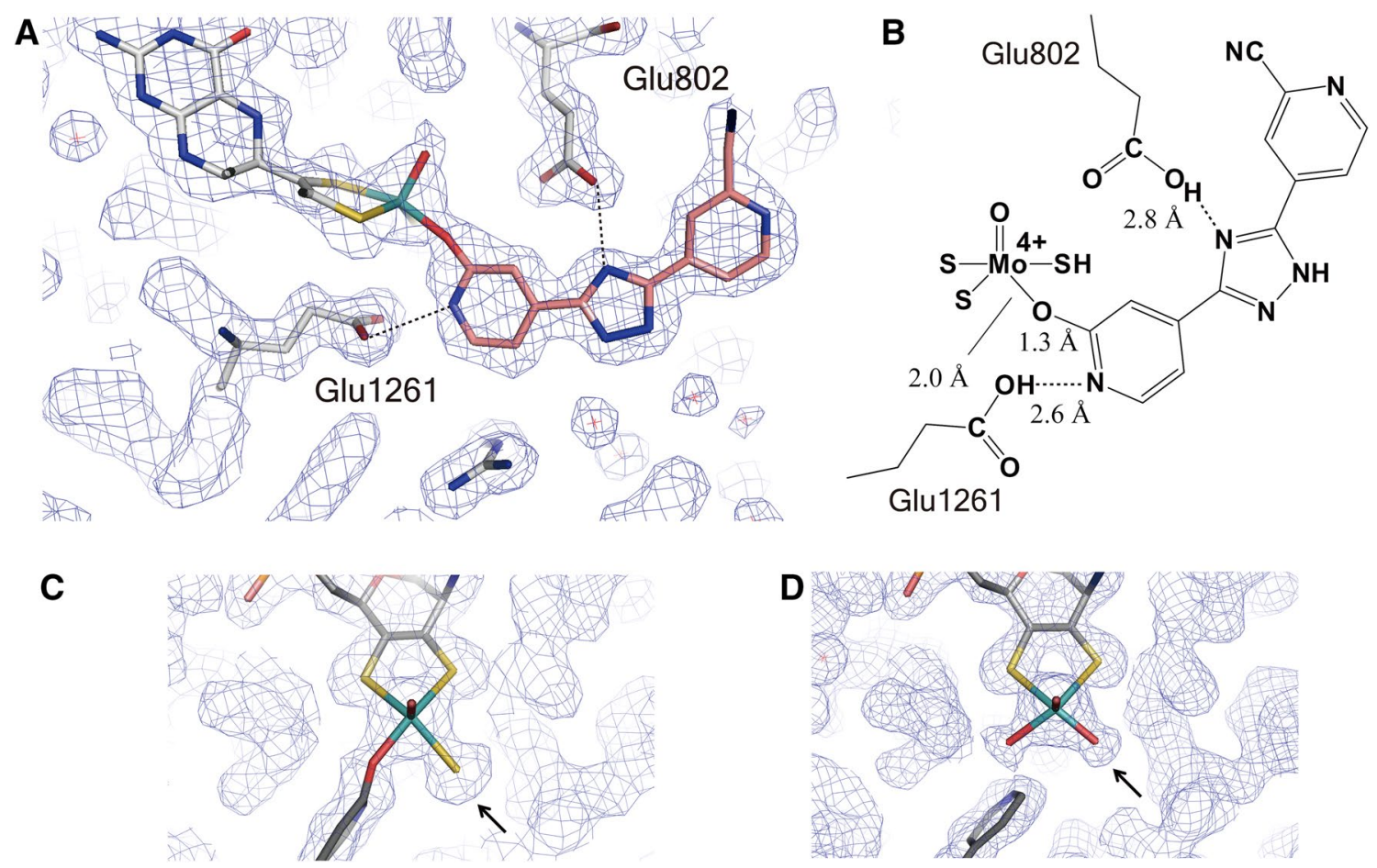

Fig. 5 Crystal structure of topiroxostat (FYX-051) bound to XOR and binding modes of substrates. A Electron-density map around the Mo atom in the complex of fully active XOR with topiroxostat. B Interaction of amino acid residues in the protein cavity. Two protonated glutamate residues, E802 and E1261, are at hydrogen-bonding distances from $\mathrm{N}$ atoms of topiroxostat. $\mathrm{C}$ Electron density around the Mo atom in the complex of fully active XOR with topiroxostat, showing electron density between Mo and a carbon atom of topirox-

water molecule was observed in the crystal structure of the topiroxostat-XOR complex, probably because the site is fully occupied by a bulky hydrophobic molecule [99].

\section{Mechanism of hydroxylation of purine substrates}

We previously reviewed the hydroxylation mechanism at the Moco site in this journal in 2008 [10]. As described then, two contradictory models have been proposed for the substrate-binding mode and activation mechanism. We revisit this issue here because, despite further research [105-108], the issue remains controversial [15, 106, 109]. The first model shown in Fig. 6A-a is based on site-directed studies [40], the binding mode of oxipurinol explored by $\mathrm{X}$-ray structure analyses with $R$. capsulatus XDH [38] and with bovine XOR [98], and the mechanism in the case of topiroxostat [99]. Nucleophilic reaction is activated or facilitated through hydrogen bonds formed between the substrate and amino acid residues, particularly by Glu1261, as described in the section on topiroxostat. The same authors subsequently presented X-ray data at high ostat. See similar electron densities of two sulfur atoms connected to pterin moiety. D Electron density around the Mo atom in the case of inactive desulfo-XOR, showing no electron density between Mo and a carbon atom. Lower electron density is observed, similar to that another oxygen atom coordinated to the equatorial position. Both are viewed from the apical position. Differences in electron density are indicated by arrows

resolution showing the binding mode of demolybdo-XOR and urate [105]. These binding modes are consistent with the metabolic sequence, i.e., hydroxylation at the 2-position of hypoxanthine precedes that at the 8-position. That is, interaction of the 2-position keto group $(\mathrm{C}=\mathrm{O})$ and $\operatorname{Arg} 881$ is important for efficient hydroxylation at the 8-position, as discussed in connection with mutagenesis studies [10, 40]. The other mode does not have such an interaction. This is consistent with the report that mutation of the corresponding arginine to glutamate in A. nidulans XOR resulted in loss of xanthine hydroxylation activity, though activity towards hypoxanthine still remained [110].

Another binding mode and activation mechanism were proposed by Hille et al. [111, 112] (Figure 6A-b), in which negative charge can be accumulated at the 6-position oxygen through interaction with the positive charge of the guanidinium group of $\operatorname{Arg} 880$; this would be energetically more favorable. A classification scheme for bad (slow) (Fig. 6A-a) and good (fast) (Fig. 6A-b) substrates was proposed based on their orientation in the active site, in the light of experimental data for 2-hydroxy-6-methylpurine as a substrate and for the xanthine-bound desulfo form 
A
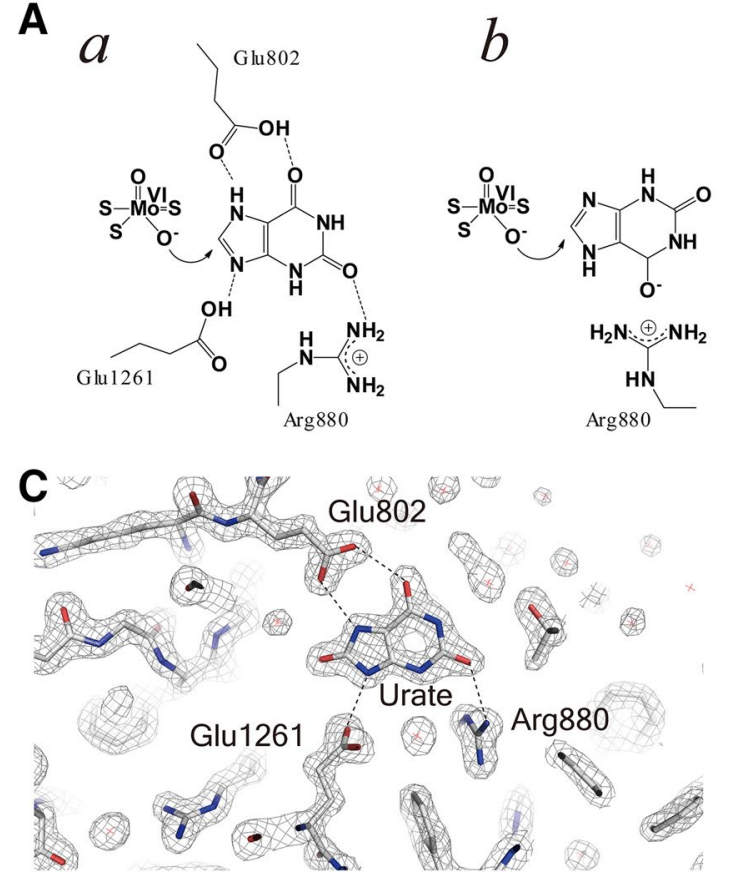

Fig. 6 Crystal structure of XOR with oxipurines. A Two binding models have been proposed. (a) Binding mode proposed by the authors of this paper. $(b)$ Binding mode proposed by Hille et al. and Kisker et al. B Binding mode for the complex of desulfo-XOR with

of bovine XO. The former structure was considered to be a poor orientation, and therefore the reaction is slow due to high activation energy. However, the slower rate is not due to a slower rate of hydroxylation, but rather is due to a slower rate of release of the product [113].

Theoretical calculations using density-functional theory or more extensive QM/MM studies, however, supported the model shown in Fig. 6C-a [107, 114]. Since then, X-ray crystallographic studies of urate-bound demolybdo-XOR (Fig. 6C) and the urate-bound reduced Mo form (Fig. 6D) have been reported [105]. The occupancy was only around $60 \%$, and the broad electron density suggests a mixture of $s p^{3}$ and $s p^{2}$ modes; the latter might be a reaction intermediate during the reaction of xanthine hydroxylation, since it is very unstable and can be obtained at high concentration of urate. Although Glu802 was proposed to promote tautomerization of xanthine in the alternate binding mode, the water molecule located at $3 \mathrm{~N}$ and $9 \mathrm{~N}$ of xanthine (Fig. $6 \mathrm{C}$, D), should serve to assist release of the urate product [13, 114]. Figure $6 \mathrm{~B}$ shows a hypoxanthine-bound desulfo form of XOR determined in our laboratory (to be published elsewhere) that is quite different from the structure proposed by Cao et al. [106]. We have also examined the structures of a number of xanthine-bound desulfo-form XORs, but we have not obtained a clear and consistent electron density even at high resolution. We think the reason for this
B

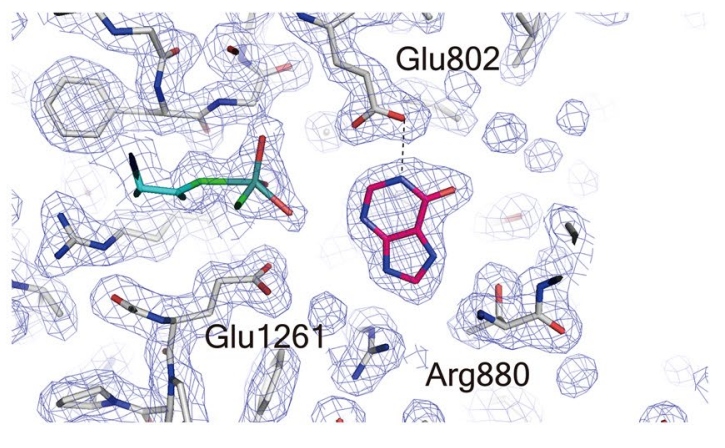

D

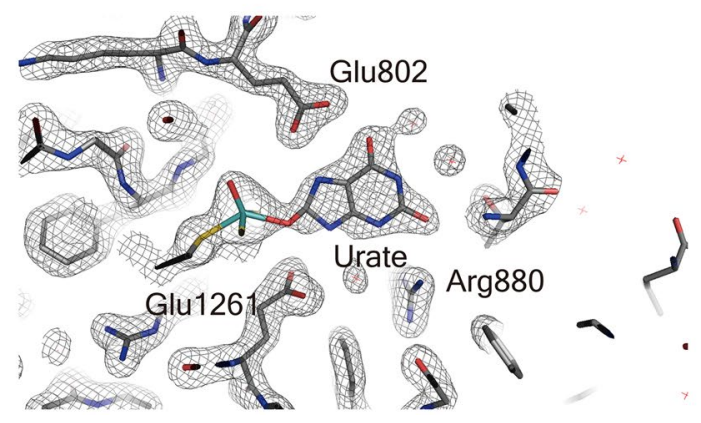

hypoxanthine obtained by the authors of this paper. C Crystal structures urate bound to demolybdo-XOR. D Urate bound to reduced Mo of fully active XOR

may be that the active-site cavity of the desulfo form can take a variety of structures for binding various substrates, indicating that X-ray structures of the desulfo form are not appropriate for discussing catalytically relevant binding modes of substrates. Subsequently, Hille et al. [15, 106, 109] presented several critiques of the urate-binding mode [105] and they provided additional data derived from site-directed mutagenesis of the R. capsulatus enzyme followed by kinetic studies after submission of this manuscript [115]. However, those kinetic data obtained with the mutant enzyme can also be explained in terms of the alternative binding mode described by Metz and Thiel [108] and the bacterial XDH exhibits different molecular dynamics around the active-site cavity from the bovine enzyme [97] that may influence the release kinetics. The focus of discussion has changed from the initial activation energy [112] to the release kinetics, and the issue of the substratebinding mode still requires clarification.

\section{Metabolic and pharmacological effects of XOR inhibition}

Possible metabolic and pathological roles of XOR are summarized schematically in Fig. 7. Metabolic effects of inhibition can generally be examined in experimental 
Fig. 7 Schematic presentation of possible metabolic and pathological roles of XOR. ROS reactive oxygen species, $N O S$ nitric oxide synthetase. $\cdot \mathrm{OH}$ can be produced under special conditions

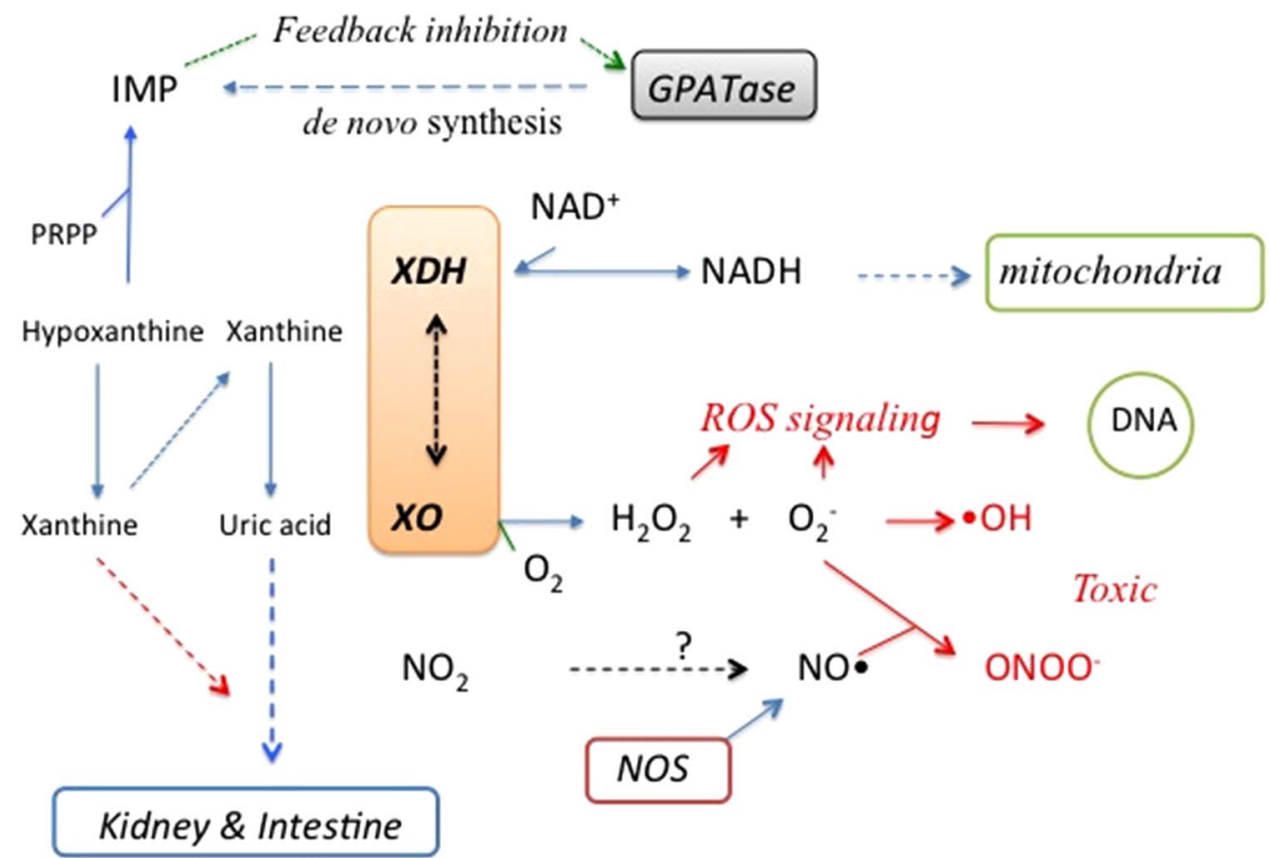

animals or humans. However, higher animals other than primates convert uric acid to more soluble allantoin (Fig. 1), catalyzed by peroxisomal uricase; and inhibitors of uricase, such as oxonic acid, are used for experiments in model animals, such as mouse or rat. In these animals, xanthine is accumulated and secreted into urine via kidney. However, hypoxanthine is less markedly accumulated, being mostly converted to IMP via hypoxanthine guanine phosphoribosyl transferase in the salvage pathway with consumption of phosphoribosyl pyrophosphate (PRPP) (Fig. 1). Accumulated ribonucleotides (AMP and GMP) inhibit the enzyme catalyzing the initial step of purine de novo synthesis, glutamine phosphoribosyl amidotransferase (GPATase) (Fig. 7), in an allosteric manner [116]. The combined effect of this feedback allosteric inhibition and consumption of PRPP might substantially reduce the size of the purine substrate pool, and this might be an effective strategy to treat hyperuricemia. On the other hand, most of the accumulated xanthine is secreted into urine. However, these animals do not seem to have tolerance for severe xanthinuria, which causes kidney damage due to xanthine stone formation [117-120] and often leads to bladder cancer [121]. Urolithiasis is sometimes accompanied with xanthinuria due to xanthine deposition, and this may occasionally lead to acute renal failure [122-127]. On the other hand, human XOR-deficient patients, possible models for inhibition of XOR, do not have such severe symptoms except in the case of type III XOR deficiency, i.e., triple deficiency of XOR, aldehyde oxidase and sulfite oxidase, due to a defect in the synthesis of Moco. Symptoms of Moco deficiency include severe neurological disorder, lens dislocation and dysmorphism, and the outcome is poor [128]. Type I xanthinuria is due to a genetic defect of XOR protein, and Type II, combined deficiency of XOR and AO, is due to a genetic defect of the enzyme catalyzing sulfide incorporation into Moco [129]. Thus, therapeutic usage of XOR inhibitors is not expected to have severe side effects if the inhibitor has no other effect than inhibition of XOR itself. However, it is still possible that patients with such genetic dysfunctions may have compensatory system(s), since systematic genetic analysis has not been carried out in xanthinuria patients [130]. It was reported that XOR can convert nitrite to nitric oxide (NO) [131-135], a vasodilator, and XORproduced NO may have a protective role in myocardial ischemia [136, 137]. Thus, potent XOR inhibitors may be contra-indicated for patients having cardio-vascular disease. However, it should be noted that NO production by $\mathrm{XO}$ is very low even under anaerobic conditions, i.e., roughly $\sim 1 \%$ of urate formation activity from xanthine [50, 138]. Maia and Moura [135] reported NO formation by AO with aldehyde substrates. It is not surprising from a chemical point of view that the water-exchangeable hydroxyl group at $\mathrm{OH}-\mathrm{Mo}(\mathrm{IV})$ can be replaced by $\mathrm{NO}_{2}$ to produce NO under strict anaerobic conditions, since various compounds, such as urate, oxipurinol and FYX-051 derivatives, can behave similarly. Nevertheless, although formation of NO is chemically feasible under strict anaerobic conditions, it is not yet clear whether these reactions have any physiological significance. Clinical studies of allopurinol, febuxostat and topiroxostat are due to start in EU countries [139]. 
As XOR has the potential to produce reactive oxygen species (ROS), inhibitors of XOR might be effective in treating XOR-associated diseases [140]. XOR exists as the $\mathrm{XDH}$ form, which does not produce ROS, under normal conditions in vivo, where $\mathrm{NAD}^{+}$exists dominantly in cytosol, because it can be isolated as the XDH form by very careful extraction procedures. Thus, production of ROS requires conversion of $\mathrm{XOR}$ to $\mathrm{XO}$ under conditions where disulfide formation or proteolysis can occur, and then XO must be secreted into the blood. The resulting XO produces $\mathrm{H}_{2} \mathrm{O}_{2}, \mathrm{O}_{2}{ }^{-}$and highly active hydroxyl radical. Further, $\mathrm{O}_{2}^{-}$ scavenges $\mathrm{NO}$ produced by nitric oxide synthetase, reacting with NO to give toxic peroxynitrite (Fig. 7). On the other hand, uric acid is known to be a good anti-oxidant $[141,142]$. The potential clinical utility of XOR inhibitors still remains to be established, although there are number of reports regarding this issue [140]. Nevertheless, XOR inhibitors should be useful tools to examine the pathophysiological significance of ROS generation by XOR.

Finally, we should comment on the possible interaction of XOR inhibitors with aldehyde oxidases (AOXs), which are also members of the molybdo-flavoenzyme family and have various physiological roles [143, 144]. All AOXs are very similar to XOR in molecular weight, cofactor composition and three-dimensional structure [145], but key residues for catalytic activity are not completely conserved in the active-site cavity, except for the glutamate residue located near the Mo atom that is important for catalytic activity. As already noted, the active-site residues are important not only for substrate specificity [40, 146], but also for binding affinity of XOR inhibitors. Further, even highly potent XOR inhibitors cannot effectively inhibit bacterial $\mathrm{XDH}$, although only minor amino acid differences are observed in the Moco domain structures that influence the molecular dynamics around the active-site cavity [97]. Thus, we think it is unlikely that highly potent XOR inhibitors would interact with AOXs. Conversely, highly potent AOX inhibitors may not interact with XOR. Nevertheless, this issue deserves further study, although as described already it is known that patients with combined XO and AOX (type II xanthinuria) deficiency due to loss of Moco sulfurase [129] do not exhibit any severe symptoms $[130,147]$.

Open Access This article is distributed under the terms of the Creative Commons Attribution License which permits any use, distribution, and reproduction in any medium, provided the original author(s) and the source are credited.

\section{References}

1. Hille R, Nishino T, Bittner F (2011) Coord Chem Rev 255:1179-1205. doi:10.1016/j.ccr.2010.11.034

2. Hille R, Nishino T (1995) FASEB J 9:995-1003
3. Schardinger F (1902) Untersuch Nahrungs Genussmittel, pp 1113-1121

4. Dixon M (1927) Biochem J 21:840-843

5. Hopkins FG (1920) Biochem J, pp 721-724

6. Harrison R (2002) Free Radic Biol Med 33:774-797

7. Berry CE, Hare JM (2004) J Physiol 555:589-606. doi:10.1113/ jphysiol.2003.055913

8. Alderman M, Aiyer KJ (2004) Curr Med Res Opin 20:369-379. doi:10.1185/030079904125002982

9. Hille R (2005) Arch Biochem Biophys 433:107-116. doi:10.1016/j.abb.2004.08.012

10. Nishino T, Okamoto K, Eger BT, Pai EF, Nishino T (2008) FEBS J 275:3278-3289. doi:10.1111/j.1742-4658.2008.06489.x

11. Nossaman VE, Nossaman BD, Kadowitz PJ (2010) Cardiol Rev 18:190-197. doi:10.1097/CRD.0b013e3181c8e14a

12. Agarwal A, Banerjee A, Banerjee UC (2011) Crit Rev Biotechnol 31:264-280. doi:10.3109/07388551.2010.527823

13. Hille R (1996) Chem Rev 96:2757-2816

14. Nishino T (1994) J Biochem 116:1-6

15. Hille R (2013) Dalton Trans 42:3029-3042. doi:10.1039/ c2dt32376a

16. Ichikawa M, Nishino T, Nishino T, Ichikawa A (1992) J Histochem Cytochem 40:1097-1103

17. Moriwaki Y, Yamamoto T, Higashino K (1999) Histol Histopathol 14:1321-1340

18. Tajima S, Nomura M, Kouchi H (2004) Front Biosci 9:1374-1381

19. Angermüller S, Islinger M, Völkl A (2009) Histochem Cell Biol 131:459-463. doi:10.1007/s00418-009-0563-7

20. Lee CC, Wu XW, Gibbs RA, Cook RG, Muzny DM, Caskey CT (1988) Science 239:1288-1291

21. Enomoto A, Kimura H, Chairoungdua A, Shigeta Y, Jutabha P, Cha SH, Hosoyamada M, Takeda M, Sekine T, Igarashi T, Matsuo H, Kikuchi Y, Oda T, Ichida K, Hosoya T, Shimokata K, Niwa T, Kanai Y, Endou H (2002) Nature 417:447-452. doi:10.1038/nature742

22. Vitart V, Rudan I, Hayward C, Gray NK, Floyd J, Palmer CN, Knott SA, Kolcic I, Polasek O, Graessler J, Wilson JF, Marinaki A, Riches PL, Shu X, Janicijevic B, Smolej-Narancic N, Gorgoni B, Morgan J, Campbell S, Biloglav Z, Barac-Lauc L, Pericic M, Klaric IM, Zgaga L, Skaric-Juric T, Wild SH, Richardson WA, Hohenstein P, Kimber CH, Tenesa A, Donnelly LA, Fairbanks LD, Aringer M, McKeigue PM, Ralston SH, Morris AD, Rudan P, Hastie ND, Campbell H, Wright AF (2008) Nat Genet 40:437-442. doi:10.1038/ng.106

23. Matsuo H, Takada T, Ichida K, Nakamura T, Nakayama A, Ikebuchi Y, Ito K, Kusanagi Y, Chiba T, Tadokoro S, Takada Y, Oikawa Y, Inoue H, Suzuki K, Okada R, Nishiyama J, Domoto H, Watanabe S, Fujita M, Morimoto Y, Naito M, Nishio K, Hishida A, Wakai K, Asai Y, Niwa K, Kamakura K, Nonoyama S, Sakurai Y, Hosoya T, Kanai Y, Suzuki H, Hamajima N, Shinomiya N (2009) Sci Transl Med 1:5ra11. doi:10.1126/scitranslmed.3000237

24. Woodward OM, Köttgen A, Coresh J, Boerwinkle E, Guggino WB, Köttgen M (2009) Proc Natl Acad Sci USA 106:1033810342. doi:10.1073/pnas.0901249106

25. Ichida K, Matsuo H, Takada T, Nakayama A, Murakami K, Shimizu T, Yamanashi Y, Kasuga H, Nakashima H, Nakamura T, Takada Y, Kawamura Y, Inoue H, Okada C, Utsumi Y, Ikebuchi Y, Ito K, Nakamura M, Shinohara Y, Hosoyamada M, Sakurai Y, Shinomiya N, Hosoya T, Suzuki H (2012) Nat Commun 3:764. doi:10.1038/ncomms 1756

26. Seegmiller JE (1965) Arthritis Rheum 8:714-725

27. Choi HK, Ford ES, Li C, Curhan G (2007) Arthritis Rheum 57:109-115. doi:10.1002/art.22466

28. Obermayr RP, Temml C, Gutjahr G, Knechtelsdorfer M, Oberbauer R, Klauser-Braun R (2008) J Am Soc Nephrol 19:24072413. doi:10.1681/ASN.2008010080 
29. Kanellis J, Kang DH (2005) Semin Nephrol 25:39-42

30. Grassi D, Desideri G, Ferri C (2014) Curr Pharm Des 20:60896095. doi: $10.2174 / 1381612820666140417095730$

31. Perticone F, Maio R, Tassone JE, Perticone M, Pascale A, Sciacqua A, Sesti G (2013) Int J Cardiol 167:232-236. doi:10.1016/j.ijcard.2011.12.065

32. Khosla UM, Zharikov S, Finch JL, Nakagawa T, Roncal C, Mu W, Krotova K, Block ER, Prabhakar S, Johnson RJ (2005) Kidney Int 67:1739-1742. doi:10.1111/j.1523-1755.2005.00273.x

33. Khanna D, Fitzgerald JD, Khanna PP, Bae S, Singh MK, Neogi T, Pillinger MH, Merill J, Lee S, Prakash S, Kaldas M, Gogia M, PerezRuiz F, Taylor W, Lioté F, Choi H, Singh JA, Dalbeth N, Kaplan S, Niyyar V, Jones D, Yarows SA, Roessler B, Kerr G, King C, Levy G, Furst DE, Edwards NL, Mandell B, Schumacher HR, Robbins M, Wenger N, Terkeltaub R, Rheumatology ACo (2012) Arthritis Care Res (Hoboken) 64:1431-1446. doi:10.1002/acr.21772

34. Arellano F, Sacristán JA (1993) Ann Pharmacother 27:337-343

35. Hung SI, Chung WH, Liou LB, Chu CC, Lin M, Huang HP, Lin YL, Lan JL, Yang LC, Hong HS, Chen MJ, Lai PC, Wu MS, Chu CY, Wang KH, Chen CH, Fann CS, Wu JY, Chen YT (2005) Proc Natl Acad Sci USA 102:4134-4139. doi:10.1073/p nas.0409500102

36. Kumar R (2011) Darpan, Sharma S, Singh R. Expert Opin Ther Pat 21:1071-1108. doi:10.1517/13543776.2011.577417

37. Enroth C, Eger BT, Okamoto K, Nishino T, Nishino T, Pai EF (2000) Proc Natl Acad Sci USA 97:10723-10728

38. Truglio JJ, Theis K, Leimkühler S, Rappa R, Rajagopalan KV, Kisker C (2002) Structure 10:115-125

39. Asai R, Nishino T, Matsumura T, Okamoto K, Igarashi K, Pai EF, Nishino T (2007) J Biochem 141:525-534. doi:10.1093/jb/ mvm054

40. Yamaguchi $Y$, Matsumura T, Ichida K, Okamoto K, Nishino T (2007) J Biochem 141:513-524. doi:10.1093/jb/mvm053

41. Page CC, Moser CC, Chen X, Dutton PL (1999) Nature 402:47-52. doi:10.1038/46972

42. Amaya Y, Yamazaki K, Sato M, Noda K, Nishino T, Nishino T (1990) J Biol Chem 265:14170-14175

43. Iwasaki $\mathrm{T}$, Okamoto $\mathrm{K}$, Nishino $\mathrm{T}$, Mizushima J, Hori $\mathrm{H}$, Nishino T (2000) J Biochem 127:771-778

44. Palmer G, Massey V (1969) J Biol Chem 244:2614-2620

45. Andrade SL, Brondino CD, Feio MJ, Moura I, Moura JJ (2000) Eur J Biochem 267:2054-2061

46. Rajagopalan KV, Johnson JL, Wuebbens MM, Pitterle DM, Hilton JC, Zurick TR, Garrett RM (1993) Adv Exp Med Biol 338:355-362

47. Maiti NC, Tomita T, Kitagawa T, Okamoto K, Nishino T (2003) J Biol Inorg Chem 8:327-333. doi:10.1007/s00775-002-0418-3

48. Waud WR, Rajagopalan KV (1976) Arch Biochem Biophys 172:354-364

49. Stirpe F (1969) Della Corte E. J Biol Chem 244:3855-3863

50. Saito T, Nishino T (1989) J Biol Chem 264:10015-10022

51. Nakamura M, Yamazaki I (1982) J Biochem 92:1279-1286

52. Hunt J, Massey V (1992) J Biol Chem 267:21479-21485

53. Sato A, Nishino T, Noda K, Amaya Y, Nishino T (1995) J Biol Chem 270:2818-2826

54. Leimkühler S, Kern M, Solomon PS, McEwan AG, Schwarz G, Mendel RR, Klipp W (1998) Mol Microbiol 27:853-869

55. Rajagopalan KV, Handler P (1967) J Biol Chem 242:4097-4107

56. Ball EG (1939) J Biol Chem, pp. 51-67

57. Corte ED, Stirpe F (1972) Biochem J 126:739-745

58. Cantu-Medellin N, Kelley EE (2013) Redox Biol 1:353-358. doi:10.1016/j.redox.2013.05.002

59. Robins RK (1956), pp. 784-790

60. Elion GB (1989) Science 244:41-47

61. Elion GB, Kovensky A, Hitchings GH (1966) Biochem Pharmacol 15:863-880
62. Spector T, Johns DG (1968) Biochem Biophys Res Commun 32:1039-1044

63. Massey V, Komai H, Palmer G, Elion GB (1970) J Biol Chem 245:2837-2844

64. Spector T, Johns DG (1970) Biochem Biophys Res Commun 38:583-589

65. Massey V, Edmondson D (1970) J Biol Chem 245:6595-6598

66. Nishino T, Usami C, Tsushima K (1983) Proc Natl Acad Sci USA 80:1826-1829

67. Gutteridge S, Tanner SJ, Bray RC (1978) Biochem J 175:887-897

68. Edmondson D, Massey V, Palmer G, Beacham LM, Elion GB (1972) J Biol Chem 247:1597-1604

69. Nishino T, Nishino T, Tsushima K (1981) FEBS Lett 131:369-372

70. Nishino T, Tsushima K (1986) J Biol Chem 261:11242-11246

71. Bray RC (1975) In: Boyer PD (ed) The enzymes. Academic Press, New York, pp 299-419

72. Godber BL, Schwarz G, Mendel RR, Lowe DJ, Bray RC, Eisenthal R, Harrison R (2005) Biochem J 388:501-508. doi:10 1042/BJ20041984

73. Godber B, Sanders S, Harrison R, Eisenthal R, Bray RC (1997) Biochem Soc Trans 25:519S

74. Moriwaki Y, Yamamoto T, Suda M, Nasako Y, Takahashi S, Agbedana OE, Hada T, Higashino K (1993) Biochim Biophys Acta 1164:327-330

75. Krenitsky TA, Spector T, Hall WW (1986) Arch Biochem Biophys 247:108-119

76. Silipo C, Hansch C (1976) J Med Chem 19:62-71

77. Springer RH, Dimmitt MK, Novinson T, O'Brien DE, Robins RK, Simon LN, Miller JP (1976) J Med Chem 19:291-296

78. Baldwin JJ, Kasinger PA, Novello FC, Sprague JM, Duggan DE (1975) J Med Chem 18:895-900

79. Wortmann RL, Ridolfo AS, Lightfoot RW, Fox IH (1985) J Rheumatol 12:540-543

80. Singh H, Sharma S, Ojha R, Gupta MK, Nepali K, Bedi PM (2014) Bioorg Med Chem Lett. doi:10.1016/j.bmcl.2014.07.041

81. Masuda T, Shingai Y, Takahashi C, Inai M, Miura Y, Honda S, Masuda A (2014) Free Radic Biol Med 69:300-307. doi:10.1016/j.freeradbiomed.2014.01.016

82. Spanou C, Veskoukis AS, Kerasioti T, Kontou M, Angelis A, Aligiannis N, Skaltsounis AL, Kouretas D (2012) PLoS One 7:e32214. doi:10.1371/journal.pone.0032214

83. Lim FP, Dolzhenko AV (2014) Eur J Med Chem 85C:371-390. doi:10.1016/j.ejmech.2014.07.112

84. Sathisha KR, Khanum SA, Chandra JN, Ayisha F, Balaji S, Marathe GK, Gopal S, Rangappa KS (2011) Bioorg Med Chem 19:211-220. doi:10.1016/j.bmc.2010.11.034

85. Niu Y, Zhu H, Liu J, Fan H, Sun L, Lu W, Liu X, Li L (2011) Chem Biol Interact 189:161-166. doi:10.1016/j.cbi.2010.12.004

86. Nepali K, Singh G, Turan A, Agarwal A, Sapra S, Kumar R, Banerjee UC, Verma PK, Satti NK, Gupta MK, Suri OP, Dhar KL (2011) Bioorg Med Chem 19:1950-1958. doi:10.1016/j.bmc.2011.01.058

87. Sharma S, Sharma K, Ojha R, Kumar D, Singh G, Nepali K, Bedi PM (2014) Bioorg Med Chem Lett 24:495-500. doi:10.1016/j.bmcl.2013.12.031

88. Shi DH, Huang W, Li C, Liu YW, Wang SF (2014) Eur J Med Chem 75:289-296. doi:10.1016/j.ejmech.2014.01.058

89. Guan Q, Cheng Z, Ma X, Wang L, Feng D, Cui Y, Bao K, Wu L, Zhang W (2014) Eur J Med Chem 85C:508-516. doi:10.1016/j.ejmech.2014.08.014

90. Nguyen MT, Nguyen NT (2013) Nat Prod Res 27:61-67. doi:10 $1080 / 14786419.2011 .652960$

91. Kaya MO, Kaya Y, Celik G, Kurtuluş F, Arslan O, Güler OO (2014) J Enzyme Inhib Med Chem. doi:10.3109/14756366.201 4.920837 
92. Chen Z, Tao H, Liao L, Zhang Z, Wang Z (2014) J Sep Sci 37:2253-2259. doi:10.1002/jssc.201400342

93. Okamoto K, Nishino T (1995) J Biol Chem 270:7816-7821

94. Sato S, Tatsumi K, Nishino T (1991) Adv Exp Med Biol 309A:135-138

95. Okamoto K, Eger BT, Nishino T, Kondo S, Pai EF, Nishino $\mathrm{T}$ (2003) J Biol Chem 278:1848-1855. doi:10.1074/jbc. M208307200

96. Fukunari A, Okamoto K, Nishino T, Eger BT, Pai EF, Kamezawa M, Yamada I, Kato N (2004) J Pharmacol Exp Ther 311:519-528. doi:10.1124/jpet.104.070433

97. Kikuchi H, Fujisaki H, Furuta T, Okamoto K, Leimkühler S, Nishino T (2012) Sci Rep 2:331. doi:10.1038/srep00331

98. Okamoto K, Eger BT, Nishino T, Pai EF, Nishino T (2008) Nucleosides Nucleotides Nucleic Acids 27:888-893. doi:10.1080/15257770802146577

99. Okamoto K, Matsumoto K, Hille R, Eger BT, Pai EF, Nishino T (2004) Proc Natl Acad Sci USA 101:7931-7936. doi:10.1073/p nas.0400973101

100. Matsumoto K, Okamoto K, Ashizawa N, Nishino T (2011) J Pharmacol Exp Ther 336:95-103. doi:10.1124/jpet.110.174540

101. Huber R, Hof P, Duarte RO, Moura JJ, Moura I, Liu MY, LeGall J, Hille R, Archer M, Romão MJ (1996) Proc Natl Acad Sci USA 93:8846-8851

102. Jones RM, Inscore FE, Hille R, Kirk ML (1999) Inorg Chem 38:4963-4970

103. Bordas J, Bray RC, Garner CD, Gutteridge S, Hasnain SS (1980) Biochem J 191:499-508

104. Leimkühler S, Stockert AL, Igarashi K, Nishino T, Hille R (2004) J Biol Chem 279:40437-40444. doi:10.1074/jbc. M405778200

105. Okamoto K, Kawaguchi Y, Eger BT, Pai EF, Nishino T (2010) J Am Chem Soc 132:17080-17083. doi:10.1021/ja1077574

106. Cao H, Pauff JM, Hille R (2010) J Biol Chem 285:2804428053. doi:10.1074/jbc.M110.128561

107. Metz S, Thiel W (2009) J Am Chem Soc 131:14885-14902. doi: $10.1021 / \mathrm{ja} 9045394$

108. Metz S, Thiel W (2010) J Phys Chem B 114:1506-1517. doi:10.1021/jp909999s

109. Hille R, Hall J, Basu P (2014) Chem Rev 114:3963-4038. doi:10.1021/cr400443z

110. Glatigny A, Hof P, Romão MJ, Huber R, Scazzocchio C (1998) J Mol Biol 278:431-438. doi:10.1006/jmbi.1998.1707

111. Dietzel U, Kuper J, Doebbler JA, Schulte A, Truglio JJ, Leimkühler S, Kisker C (2009) J Biol Chem 284:8768-8776. doi:10.1074/jbc.M808114200

112. Pauff JM, Zhang J, Bell CE, Hille R (2008) J Biol Chem 283:4818-4824. doi:10.1074/jbc.M707918200

113. McWhirter RB, Hille R (1991) J Biol Chem 266:23724-23731

114. Bayse CA (2009) Dalton Trans. doi:10.1039/b821878a

115. Hall J, Reschke S, Cao H, Leimkuhler S, Hille R (2014) J Biol Chem. doi:10.1074/jbc.M114.603456

116. Smith JL, Zaluzec EJ, Wery JP, Niu L, Switzer RL, Zalkin H, Satow Y (1994) Science 264:1427-1433

117. Kucera J, Bulkova T, Rychla R, Jahn P (1997) J Small Anim Pract 38:302-305

118. van Zuilen CD, Nickel RF, van Dijk TH, Reijngoud DJ (1997) Vet Q 19:172-174. doi:10.1080/01652176.1997.9694766

119. Tsuchida S, Kagi A, Koyama H, Tagawa M (2007) J Feline Med Surg 9:503-508. doi:10.1016/j.jfms.2007.03.012

120. Miranda M, Rigueira L, Suarez ML, Carbajales P, Moure P, Fidalgo LE, Failde D, Vazquez S (2010) J Vet Med Sci 72:921-923

121. Shimo T, Moto M, Ashizawa N, Oba K, Nagata O (2011) Drug Chem Toxicol 34:192-198. doi:10.3109/01480545.2010.500291
122. Bradbury MG, Henderson M, Brocklebank JT, Simmonds HA (1995) Pediatr Nephrol 9:476-477

123. Thomas N, Stephen DC, Abraham B, Kekre N, Seshadri MS (1996) J Assoc Physicians India 44:203-204

124. Kiss A, Barenyi M, Csontai A (1999) Urol Int 63:242-244

125. Al-Eisa AA, Al-Hunayyan A, Gupta R (2002) Int Urol Nephrol 33:3-6

126. Arikyants N, Sarkissian A, Hesse A, Eggermann T, Leumann E, Steinmann B (2007) Pediatr Nephrol 22:310-314. doi:10.1007/ s00467-006-0267-3

127. Gargah T, Essid A, Labassi A, Hamzaoui M, Lakhoua MR (2010) Saudi J Kidney Dis Transpl 21:328-331

128. Scriver CR, Childs B, Kinzler KW, Vogelstein B (2001) The metabolic and molecular bases of inherited disease. McGrawHill, New York

129. Ichida K, Matsumura T, Sakuma R, Hosoya T, Nishino T (2001) Biochem Biophys Res Commun 282:1194-1200. doi:10.1006/b brc.2001.4719

130. Ichida K, Amaya Y, Okamoto K, Nishino T (2012) Int J Mol Sci 13:15475-15495. doi:10.3390/ijms131115475

131. Millar TM, Stevens CR, Benjamin N, Eisenthal R, Harrison R, Blake DR (1998) FEBS Lett 427:225-228

132. Zhang Z, Naughton D, Winyard PG, Benjamin N, Blake DR, Symons MC (1998) Biochem Biophys Res Commun 249:767772. doi:10.1006/bbrc. 1998.9226

133. Godber BL, Doel JJ, Sapkota GP, Blake DR, Stevens CR, Eisenthal R, Harrison R (2000) J Biol Chem 275:7757-7763

134. Li H, Samouilov A, Liu X, Zweier JL (2001) J Biol Chem 276:24482-24489. doi:10.1074/jbc.M011648200

135. Maia LB, Moura JJ (2011) J Biol Inorg Chem 16:443-460. doi:10.1007/s00775-010-0741-z

136. Webb AJ, Milsom AB, Rathod KS, Chu WL, Qureshi S, Lovell MJ, Lecomte FM, Perrett D, Raimondo C, Khoshbin E, Ahmed Z, Uppal R, Benjamin N, Hobbs AJ, Ahluwalia A (2008) Circ Res 103:957-964. doi:10.1161/CIRCRESAHA.108.175810

137. Baker JE, Su J, Fu X, Hsu A, Gross GJ, Tweddell JS, Hogg N (2007) J Mol Cell Cardiol 43:437-444. doi:10.1016/j.yjmcc.2007.07.057

138. Massey V, Brumby PE, Komai H (1969) J Biol Chem 244:1682-1691

139. MacDonald TM, Ford I, Nuki G, Mackenzie IS, De Caterina R, Findlay E, Hallas J, Hawkey CJ, Ralston S, Walters M, Webster J, McMurray J, Perez Ruiz F, Jennings CG (2014) BMJ Open 4:e005354. doi: 10.1136/bmjopen-2014-005354

140. Pacher P, Nivorozhkin A, Szabó C (2006) Pharmacol Rev 58:87-114. doi:10.1124/pr.58.1.6

141. Ames BN, Cathcart R, Schwiers E, Hochstein P (1981) Proc Natl Acad Sci USA 78:6858-6862

142. Rock KL, Kataoka H, Lai JJ (2013) Nat Rev Rheumatol 9:1323. doi:10.1038/nrrheum.2012.143

143. Garattini E, Terao M (2013) Expert Opin Drug Discov 8:641654. doi:10.1517/17460441.2013.788497

144. Marelja Z, Dambowsky M, Bolis M, Georgiou ML, Garattini E, Missirlis F, Leimkühler S (2014) J Exp Biol 217:2201-2211. doi:10.1242/jeb.102129

145. Coelho C, Mahro M, Trincão J, Carvalho AT, Ramos MJ, Terao M, Garattini E, Leimkühler S, Romão MJ (2012) J Biol Chem 287:40690-40702. doi:10.1074/jbc.M112.390419

146. Mahro M, Brás NF, Cerqueira NM, Teutloff C, Coelho C, Romão MJ, Leimkühler S (2013) PLoS One 8:e82285. doi:10.1371/journal.pone.0082285

147. Simmonds HA, Reiter S, Nishino T (1995) In: Scriver CR (ed) The metabolic and molecular bases of inherited disease. McGrawHill Health Professions Division, New York, pp 1781-1797 